\title{
CLIMATE CHANGE IN ANTARCTIC AND MAGELLANIC REGIONS: FIELDS AND GOALS OF SCIENTIFIC COOPERATION ${ }^{1}$
}

\author{
CAMBIO CLIMÁTICO EN LAS REGIONES ANTÁRTICA Y DE MAGALLANES: \\ CAMPOS Y OBJETIVOS DE LA COOPERACIÓN CIENTÍFICA
}

Wolf E. Arntz ${ }^{2} \&$ Dieter Gerdes ${ }^{3}$

Dealing with climate change in polar and subpolar waters of the southern hemisphere, the Magellan region is in a particularly favourable position. During geological history up to the present time, this area has been influenced by, and many times involved in, Antarctic and Subantarctic climate change. Life in its waters is still reflecting the consequences of the latest glaciation. Of all land masses surrounding the Antarctic, it lies at a relatively close distance, is the only one connected by a bridge of islands and shallows, and its marine fauna shows the greatest similarity with that of South Polar regions. Furthermore, scientists of most countries doing Antarctic marine research pass the Magellan region on their way to and from the Antarctic, and many research vessels use Punta Arenas (Chile) or Ushuaia (Argentina) as their last continental base for refuelling and replenishing provisions.

In the past decades, Antarctic research has increased in importance, and various cooperative projects have made use of the facilities and research opportunities offered in the Cono Sur. In particular the IBMANT project has made an effort to study the biological interactions between the Magellanic and Antarctic provinces, revealing a considerable degree of relatedness. The data collected in this project and in others such as SCAR`s EASIZ and EBA, the Chilean CIMAR-FIORDO or more recent campaigns in the context of CAML and the International Polar Year can now be used as baselines to identify the effects that may be attributed to regional warming.

Scientific cooperation in the Antarctic is by no means recent; in fact it is one of the paradigms underlying the Antarctic Treaty signed by 12 nations in December 1959: "Freedom of scientific investigation in Antarctica and cooperation as applied during the IGY shall continue" (Article 2);"Plans for scientific programmes and the observations and results thereof shall be freely exchanged; scientists may

1 An earlier version of this paper was presented at the International Colloquium Climate Change in Magellan and Antarctic Regions: Evidence and Challenges for the Future (27 - 31 October 2009, Punta Arenas, Chile)

2 Alfred Wegener Institute für Polar und Meeresforschung, Columbusstraße, 27568, Bremerhaven, Germany. petzarntz@ online.de

3 Alfred Wegener Institute für Polar und Meeresforschung, Columbusstraße, 27568, Bremerhaven, Germany. dieter.gerdes@ awi.de 
be exchanged between expeditions" (Article 3). Since then further 35 nations have become signatories, however only 28 countries have qualified so far to attend the ATCM by conducting substantial research activities.

\section{Past cooperation}

Many of the research activities in the Antarctic have been coordinated by the Scientific Committee on Antarctic Research (SCAR), which was founded in 1957 as a Subcommittee of ICSU. SCAR has developed a substantial number of Groups of Specialists, Subcommittees and Programmes, which addressed climate change issues at an early stage. In the 1990ies, the GLOCHANT office (cf. Table 1 for abbreviations and acronyms) linked 6 different SCAR programmes related to climate change.

Among the few large programmes that were not coordinated by SCAR, two IGBP programmes must be mentioned. SO-JGOFS carried out mainly biogeochemical work in the Southern Ocean, only to $60^{\circ} \mathrm{S}$, addressing the role of the Southern Ocean (SO) in the global carbon cycle and the fate of primary production, but also the role of salps and krill. SOGLOBEC worked in Antarctic and Subantarctic waters and was dealing with the life cycle of zooplankton, mainly krill, and its predators. The US part of SOJGOFS was run under the label AESOPS. Both programmes have major core programmes outside the $\mathrm{SO}$ and are now in the synthesis phase. Results can be found, e.g. in Strass and further cit. therein (2002), Smith \& Anderson (2003) and Hofmann et al. $(2004,2009)$.

The first large SCAR programme, supported by SCOR and FAO, was BIOMASS, which gave rise to the creation of CCAMLR. BIOMASS was principally directed towards the Antarctic krill, which was thought to be fully available after the collapse of the large baleen whale stocks, and other living resources of the SO. Its aim was also to improve the understanding of the ecology of the $\mathrm{SO}$ as well as the management of its living resources. Three multi-vessel expeditions were carried out between 1980 and 1985, the first of which (FIBEX) integrated the work of 11 nations on the same number of vessels. While FIBEX was a quasi-synoptic survey over three sectors of the SO, SIBEX I and II produced a temporal sequence of observations in smaller areas of Bransfield Strait and Prydz Bay. A summary of the BIOMASS investigations was given by El Sayed (1994).

Large-scale international cooperation on a single vessel became possible with the construction of the German icebreaker "Polarstern" from 1983. Soon embarking foreigners on this large vessel, which provides the necessary space and facilities, became a routine. On six cruises with a focus on Antarctic benthos between 1989 and 2004, 280 scientists from 19 nations participated, with an average of 9 nations per cruise (Fig. 1). The relation of Germans to foreigners for this period was $53: 47 \%$. This is

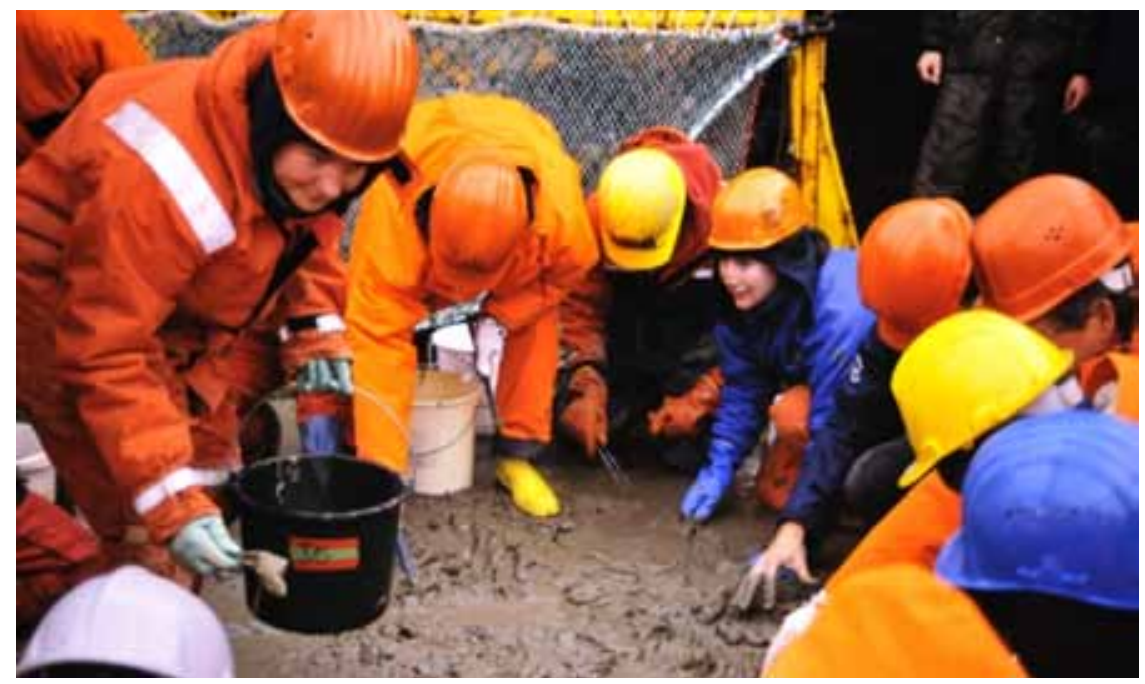

Fig. 1. Scientists from several countries checking the Agassiz trawl catch onboard the German RV 'Polarstern'. 
Table 1. List of acronyms and abbreviations used in the text.

\begin{tabular}{|c|c|}
\hline ACC & Antarctic Circumpolar Current \\
\hline AESOPS & US Antarctic Southern Ocean Environment Study \\
\hline ANDEEP & Antarctic Benthic Deep-Sea Biodiversity \\
\hline APIS & Antarctic Pack Ice Seals \\
\hline ATCM & Antarctic Treaty Consultative Meetings \\
\hline BAS & British Antarctic Survey \\
\hline BENDEX & Benthic Disturbance Experiment \\
\hline BIOMASS & Biological Investigations of Marine Antarctic Systems and Stocks \\
\hline BOLD & Barcode of Live \\
\hline CADIC & Centro Austral de Investigaciones Científicas \\
\hline CAML & Census of Antarctic Marine Life \\
\hline CCAMLR & Commission for the Conservation of Antarctic Marine Living Resources \\
\hline CENPAT & Centro Nacional Patagónico \\
\hline CIEP & Centro de Investigación en Ecosistemas de la Patagonia \\
\hline CIMAR-Fiordo & Crucero de Investigación Científica a los Fiordos y Canales Adyacentes a Campos de Hielo Sur \\
\hline CoML & Census of Marine Life \\
\hline CONICYT & Consejo de Investigación Científica y Tecnológica \\
\hline EASIZ & Ecological Studies in the Antarctic Sea Ice Zone \\
\hline EBA & Evolution and Biodiversity in the Antarctic \\
\hline EoL & Encyclopedia of Life \\
\hline EPOS & European "Polarstern" Study \\
\hline EULA & Environmental Science Center Univ. Concepción \\
\hline EVOLANTA & Evolution of Antarctic Organisms \\
\hline FAO & Food and Agriculture Organisation of the United Nations \\
\hline FIBEX & First International BIOMASS Experiment \\
\hline GLOBEC & Global Ocean Ecosystem Dynamics \\
\hline GLOCHANT & Global Change in the Antarctic \\
\hline IBMANT & $\begin{array}{l}\text { Investigación Biológica Marina en Magallanes relacionada con la Antártida } \\
\text { (Marine Biological Investigation in the Magellan region related to the Antarctic) }\end{array}$ \\
\hline IGBP & International Geosphere Biosphere Programme \\
\hline IGY & International Geophysical Year \\
\hline ICSU & International Council for Science \\
\hline INACH & Instituto Antártico Chileno \\
\hline IPCC & Intergovernmental Panel on Climate Change \\
\hline IPY & International Polar Year \\
\hline JGOFS & Joint Global Ocean Flux Study \\
\hline LAMPOS & Latin America "Polarstern" Expedition \\
\hline MarBIN & Marine Biodiversity Information Network \\
\hline RAMS & Register of Antarctic Marine Species \\
\hline RiSCC & Regional Sensitivity to Climate Change in Antarctic Terrestrial and Limnetic Ecosystems \\
\hline SCAR & Scientific Committee on Antarctic Research \\
\hline SCOR & Scientific Committee on Oceanic Research \\
\hline SIBEX & Second International BIOMASS Experiment \\
\hline $\mathrm{SO}$ & Southern Ocean \\
\hline UMAG & Universidad de Magallanes \\
\hline WBGU & Wiss. Beirat der Bundesregierung Globale Umweltveränderungen \\
\hline WWF & World Wide Fund for Nature \\
\hline
\end{tabular}


Table 2. 'Polarstern' expeditions with focus on benthic research.

\begin{tabular}{lccc}
\hline Cruise & Acronym & Date & Region \\
\hline ANT VII-2-4 & EPOS I-3 & $13.01 .-10.03 .1989$ & SE Weddell Sea shelf \\
ANT XIII-3 & EASIZ I & $26.01 .-15.03 .1996$ & SE Weddell Sea shelf \\
ANT XIII-4 & & $17.04 .-20.05 .1996$ & Eastern South American continental shelf \\
ANT XV-3 & EASIZ II & $13.01 .-26.03 .1998$ & SE Weddell Sea, Peninsula \\
ANT XVII-3 & EASIZ III & $18.03 .-11.05 .2000$ & SE Weddell Sea, Peninsula \\
ANT XIX-5 & LAMPOS & $03.04 .-05.05 .2002$ & Scotia Arc \\
ANT XXI-2 & BENDEX & $17.11 .2003-18.01 .2004$ & SE Weddell Sea shelf \\
ANT XXIII-8 & LARSEN & $23.11 .2006-30.01 .2007$ & Peninsula, Larsen A,B
\end{tabular}

highly unusual on the international scene, but has been a great advantage not only for the foreigners but also for German ecological research in the South Polar Sea. The first really international cruise was EPOS with three legs following the receding packice edge between October 1988 and March 1989 and the focus shifting successively from sea ice ecology to the pelagic and benthic realms. Results of EPOS were published in Hempel (1993) and successive papers.

EASIZ was established as a programme of SCAR`s Biology WG in 1994 and lasted until 2004. Its objectives were to study biological structures and processes in the Antarctic pack ice zone. It was principally directed towards the benthic realm but included studies on sea ice biota and coupling processes in the water column, as well as warm-blooded animals as far as these were not covered by APIS, another SCAR programme. EASIZ was the major biological SCAR successor programme to BIOMASS and complementary to SO-GLOBEC and SO-JGOFS. As seasonal pack ice also occurs at the Antarctic Peninsula, EASIZ enabled the participation of vessels with lower ice resistance and of several land-based stations. Major inputs to EASIZ came from three "Polarstern" cruises between 1996 and 2000 and a final one (BENDEX), with an experimental approach to the effects of iceberg scouring, in 2003/04 (Table 2). Results of EASIZ were published in two symposium volumes by Arntz \& Clarke (2002) and Clarke et al. (2006a), among others.

EASIZ also contributed to IBMANT, which never had the status of an official SCAR programme but developed as a German-South American cooperative initiative parallel to EASIZ. Starting from the similarity of certain faunal elements in Antarctic and Magellanic waters, IBMANT combined scientists with Antarctic and Magellanic experience and carried out two specific cruises, the "Victor Hensen" campaign in the Magellan region in 1994 and LAMPOS on RV "Polarstern", covering the Scotia Arc, in autumn 2002. Furthermore, two symposia in Punta Arenas and Ushuaia were organized under the IBMANT umbrella (results published in Arntz \& Ríos 1999 and Arntz et al. 2005). Before that, the Italian vessel "Italica" had already carried out cooperative work in the Straits of Magellan with Centro EULA-Chile and the University of Concepción (Gallardo et al. 1992), and the Chilean CIMAR-Fiordo cruises, with occasional participation of foreigners, had contributed to the IBMANT concept and improved knowledge about the Magellanic channel system (e.g., Mutschke et al. 1999, Thatje \& Brown 2009).

Another "independent" collaborative programme was ANDEEP under the Census of Marine Life (CoML), with three international "Polarstern" cruises studying deep-sea biodiversity between 2002 and 2005. Sampling deep-sea floors between the Drake Passage and the southeastern Weddell Sea yielded a surprising variety of species, $>1400$ altogether, more than half of which were new. The bathymetric range of many species living at depth turned out to be very wide. Results of ANDEEP were published, a.o., in Brandt \& Hilbig (2004).

\section{Ongoing cooperation}

One important result of SCAR programmes such as EVOLANTA, EASIZ and RiSCC had been that the Antarctic biota in the pack ice system and ashore is probably quite vulnerable to climate change, not only in terms of recent biodiversity but also concerning evolutionary processes. The same is true for the Subantarctic and the Magellan region (Smith, 2002; Barnes, 2005). This led to the establishment of another SCAR programme by 
the Standing Scientific Committee on Life Sciences, which is uniting research on recent and past biota and ecosystems, as well as marine, terrestrial, and limnic environments. EBA, presently SCAR`s biological flagship programme, is still continuing (2006-2013). As a programme intimately related to climate change, it sails under the slogan "Describe the past, understand the present, predict the future" and seeks to:

- understand the evolution and diversity of life in the Antarctic;

- determine how these have influenced the properties and dynamics of present Antarctic ecosystems and the SO system;

- make predictions on how organisms and communities will respond to current and future environmental change; and

- identify EBA science outcomes that are relevant to conservation policy and communicate this science via the SCAR Antarctic Treaty System Committee.

EBA incorporates CAML, the SO Plankton Recorder Survey, SCAR MarBIN, the Expert Group on Marine Birds and Mammals, and SCAR services such as the Antarctic Biodiversity Database. Besides being a part of EBA, CAML is also a field project of CoML and a major initiative of the International Polar Year (IPY). Its duration was to be 5 years until 2009; however an application for extension was submitted for 2010. Work at sea was finished in the 2009/10 season but analyses are continuing. CAML is directly addressing questions related to climate change, as can be seen from the aims and objectives:

(project goal) "...investigate diversity, distribution and abundance of Antarctic marine life (from microbes to whales), how it is affected by climate change, and how this change will alter ecosystem services..."

(objectives) “... add value and scientific insight by coordinating the marine biodiversity research of Antarctic nations, particularly during the IPY... establish a robust benchmark of Antarctic biodiversity, against which future change can be measured..."

CAML has coordinated participation in 18 voyages on research icebreakers and the analysis of samples and data, adopted uniform sampling methods for all vessels, unified shipboard gear, systematics, DNA barcoding, organizes workshops, data analysis, description of new species, synthesizes scientific publications, organizes education, and provides outreach to inform the public at large.

Furthermore, CAML, in cooperation with oceanographers, created a Southern Ocean Information System in 2007, and contributes to SCAR MarBIN, with access to RAMS and its genetic component GenBank storing DNA barcodes, which can be linked to specific locations. It also contributes to the Barcode of Life (BOLD) and to the Encyclopedia of Life (EoL), mainly providing invertebrate data (CAML 2009).

While international shipboard cooperation, either by scientists from various nations on one vessel or among nations on their respective vessels, has been a very efficient way to tackle complex questions in polar waters, smaller bilateral or multilateral projects at land-based stations have also contributed their share. Some of these stations receive foreign guests routinely. At the joint Dallman laboratory, an annex to the Argentinean station Teniente Jubany, Argentineans and Germans have maintained a close cooperation since 1991 (Wiencke et al. 2008). A similar case in another field is the Chilean-German collaboration at the O'Higgins satellite station. The impressive variety of international cooperative encounters of Antarctic scientists is completed by SCAR symposia, open science conferences and other scientific meetings organized by the different programmes. Altogether, this international cooperation seems to work better than national efforts in the Magellan region, with the consequence that some frequently visited areas in the Antarctic are much better known than many of the seas, channels and fjords of the Cono Sur.

\section{Climate change is underway}

Since the latest IPCC Report (IPCC 2007), public awareness of global warming and its actual and future consequences has greatly increased. 8 of 10 of the warmest years since 1900 were registered in the 1990s, which may well have been the warmest decade of the last 1000 years. Particularly the Arctic has shown a strong temperature increase of 3 to $4^{\circ} \mathrm{C}$ since 1950 , sea ice thickness in this region has decreased by $8 \%$, sea ice extension by $2.5 \%$ per decade. Glaciers are retreating worldwide.

High-latitude warming in the southern hemisphere is occurring at a somewhat slower pace due to the effect of the enormous East Antarctic ice cap, 


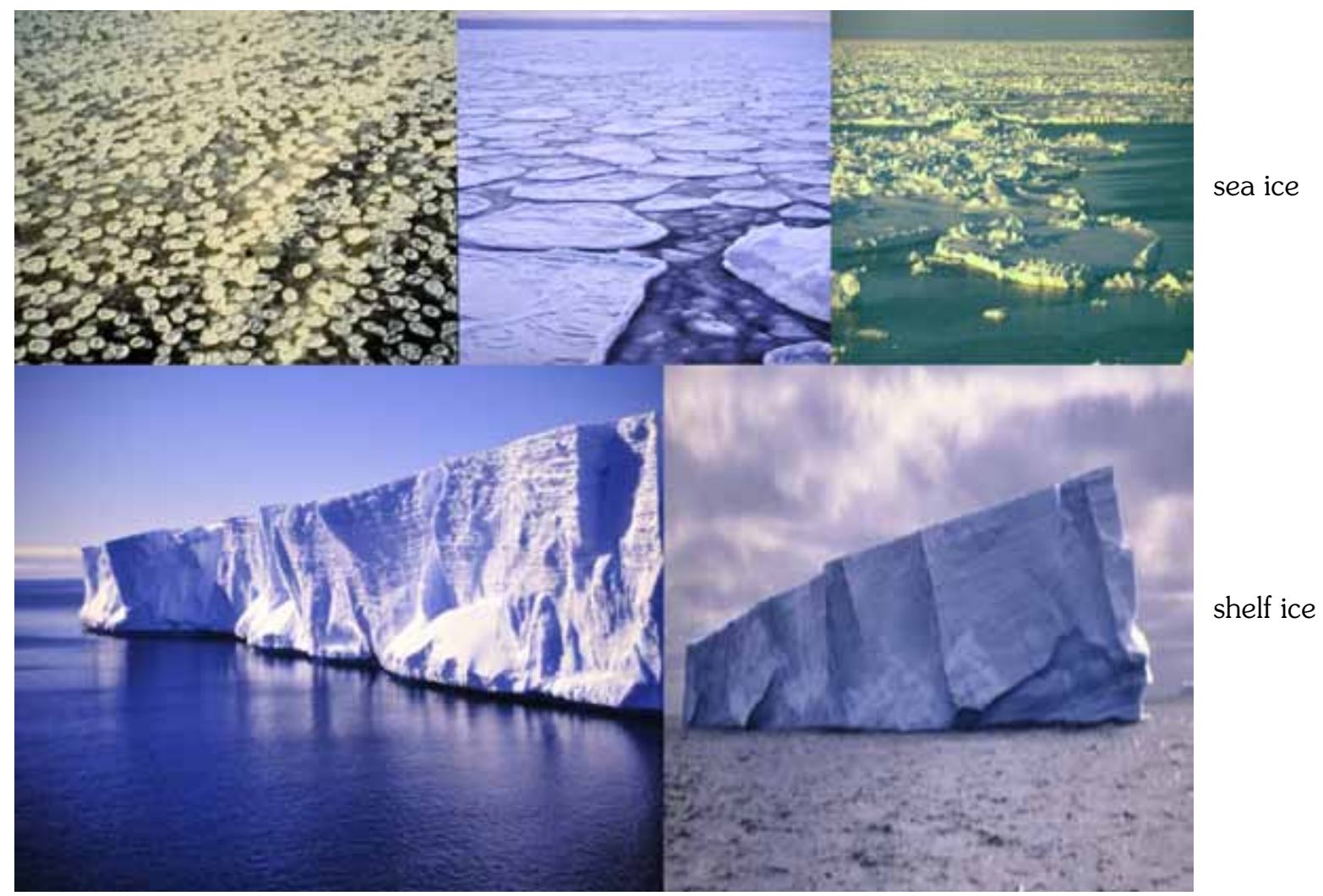

Fig. 2. Ice formations: from pancake ice to shelf ice.

which does not yet respond clearly to ongoing climate change, due to the isolation of the continent by the Antarctic Circumpolar Current and stronger winds occurring further south (see below). Evidence of overall warming is weak in station data from continental Antarctica; in the dry valleys air temperature even dropped by $0.7^{\circ} \mathrm{C}$ per decade in the $20^{\text {th }}$ century (IPCC 2007). However, annual mean air temperatures at the Beagle Channel increased by $1^{\circ} \mathrm{C}$ in the last century (Smith \& Reynolds 2004), and most glaciers in the Patagonian Icefields and the Darwin Cordillera are retreating (Warren \& Aniya 1999). Mean air temperatures at the Antarctic Peninsula and over the Bellingshausen Sea have warmed by $>1.5^{\circ} \mathrm{C}$ since 1950 and by $>3^{\circ} \mathrm{C}$ in the last century (Vaughan et al. 2003); Faraday and Vernadsky stations even registered a warming of $0.53^{\circ} \mathrm{C}$ per decade in the past 50 years (Turner et al. 2009), and according to Quayle et al. (2002), summer air temperatures on Signy Island have increased by $1^{\circ} \mathrm{C}$ over the last 50 years. Warming is no longer restricted to the Antarctic Peninsula and the maritime
Antarctic, but covers most of the West Antarctic, exceeding $0.5^{\circ} \mathrm{C}$ in the last 50 years (Steig et al. 2009). The West Antarctic ice sheet has thinned particularly around the Amundsen Sea embayment (Turner et al. 2009).

The upper $100 \mathrm{~m}$ layers at South Georgia are $3.3^{\circ} \mathrm{C}$ warmer in winter and $0.9^{\circ} \mathrm{C}$ warmer in summer compared to the begin of the $20^{\text {th }}$ century, and the peak temperatures in summer are occurring 6 days earlier (Whitehouse et al. 2008). The upper water layers of the Bellingshausen Sea west of the Antarctic Peninsula have warmed by $>1^{\circ} \mathrm{C}$ since 1955 , whereas warming in layers $>100 \mathrm{~m}$ depth is negligible (Meredith \& King 2005; Clarke et al. 2007). A negative trend in sea ice duration ( $>5$ days/ year) was detected off Rothera and Faraday stations. Seven ice shelves around the Antarctic Peninsula are retreating (Vaughan \& Doake 1996; Rott et al. 1996). The Wordie Ice Shelf has practically disappeared, and in 2002, 500 billion t of the Larsen B Ice Shelf disintegrated in less than a month and $3250 \mathrm{~km}^{2}$ of ice broke off (Rack \& Rott 2004). 
Variability of ice and its role in climate change

Ice in its different forms - continental ice caps, glaciers, shelf ice, icebergs, pack ice, fast ice (Fig. 2) - plays an important role for climate, weather, ocean currents and other physical properties of the ocean-atmosphere system. We will not speculate how long it may take, or which degree of warming may be required, to destabilize the East Antarctic ice cap, but the remainders of the Patagonian ice cap and the ice shelves at the Antarctic Peninsula are disintegrating rapidly. Sea ice is expected to decrease within the next 100 yrs by $33 \%$ with considerable regional variation but is especially declining in the Weddell Sea and the western Peninsula area (Zwally et al. 2002). Glaciers in many parts of the Southern Ocean, as elsewhere, are retreating dramatically (Cook et al. 2005).

Altogether these altered properties induced by climate change will affect the pelagic and the benthic system, e.g. by increasing sedimentation processes in areas adjacent to glaciers. Some specific areas are likely to experience a considerable increase in fresh water input with marked biological consequences for the shallow-water fauna in these areas. On the other hand the benthic fauna beneath the ice shelves is favoured by the disruption of ice shelves as additional shallow-water areas are uncovered and productivity is increased there. Whilst over short timescales (i.e. decades) it seems likely that ice loading and associated ice scour will increase in coastal waters, over longer timescales (i.e. centuries) it is likely that the frequency of ice scour will diminish. At this time there is no clear indication that calving of icebergs from the high Antarctic ice shelves is occurring at a faster pace.

The southern hemisphere ozone hole and its role in climate change

Careful measurements of ozone concentrations in southern polar and subpolar regions exist since the end of the 1970s, and the first report of an ozone hole over Antarctica, mainly based on measurements at Halley Bay, appeared in the mid eighties (Farman et al. 1985). Since then, minimum $\mathrm{O}_{3}$ values and the widest extension of the hole have been registered over Antarctica in southern hemisphere spring (September-October), often passing

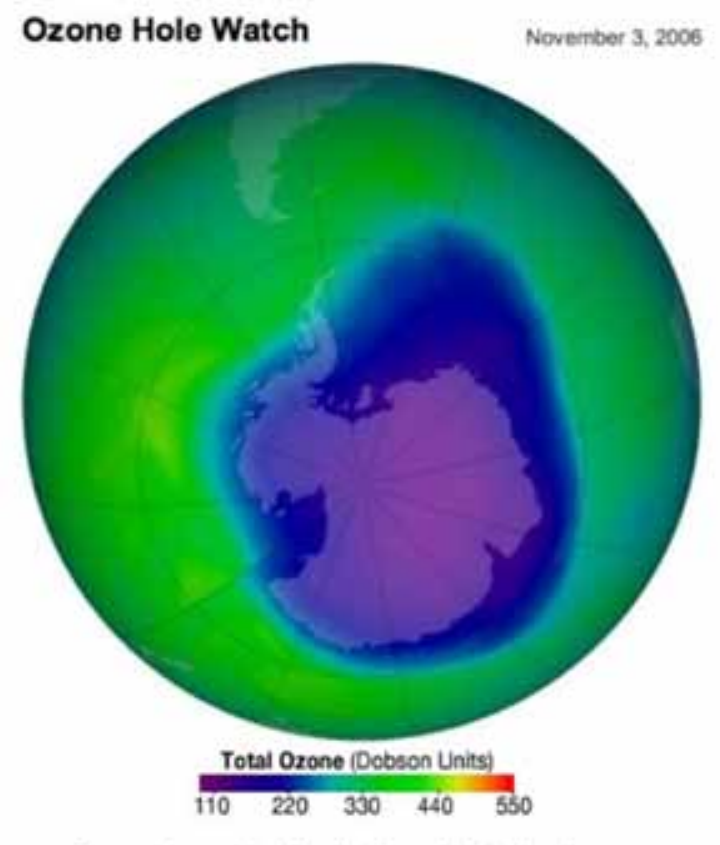

Ozone data acquired by the Ozone Monitoring Instrument on NASA's Aura satellite http://ozonewatch.gsfc.nasa.gov/

Fig. 3. Antarctic ozone hole at its record size in 2006 (http:// ozonewatch.gsfc.nasa.gov.).

on to South Georgia, the Falklands and the tip of South America (Fig. 3). In the first years after its detection, the hole kept growing to the size of the Antarctic continent. There is a certain amount of interannual variation, however since the beginning of the 1990s the extension has been relatively stable around 25 million $\mathrm{km}^{2}$.

The seasonal ozone minimum has traditionally been regarded as a climate phenomenon without closer relations to global warming, and research has concentrated on damage inflicted on photosynthesis of plants, physiology of invertebrates, sunburns of man and other vertebrates and similar effects (e.g., Cullen \& Neale 1994, Obermüller et al. 2007, Diffey 1992). By the end of 2009, however, SCAR launched a press release under www.theozonehole. com/ozonehgood.htm suggesting that it is in fact the ozone hole that has shielded most of Antarctica from global warming. As part of a major review (Turner at al. 2009), this communication states that due to the ozone hole, westerly winds over the SO have intensified by around 15\%, and have affected Antarctic weather patterns. It seems as though these winds have effectively isolated the bulk of the ice 
sheet on East Antarctica from warming elsewhere, with the consequence that surface temperatures have changed little over the greater part of the Antarctic continent.

Since 1980 there has been a 10\% increase in Antarctic sea ice extent, particularly in the Ross Sea. This is also a consequence of the stronger winds around the continent caused by the ozone hole. On the other hand, sea ice west of the Antarctic Peninsula has decreased due to southward changes in local atmospheric circulation (a common phenomenon during interglacial times, Lamy et al. 2004) and, possibly, the rapid warming over land on the west coast of the Peninsula (Turner et al. 2009).

The increased westerlies also influence Southern Ocean acidification, a worldwide consequence of increasing atmospheric $\mathrm{CO}_{2}$ concentrations and retreating ice cover. Generally, draw-down of $\mathrm{CO}_{2}$ in the world ocean has increased, and seawater is becoming more acid. Mean $\mathrm{pH}$ in the ocean has already decreased by 0.11 (IPCC 2007). However, the enhancement and southward shift of the westerly winds due to the ozone hole, which strengthens the Antarctic divergence, has affected the Southern Ocean's ability to absorb $\mathrm{CO}_{2}$ by causing stronger upwelling of $\mathrm{CO}_{2}$ rich water, thus reducing the predominant role of this ocean as a major sink of atmospheric $\mathrm{CO}_{2}$. In addition, the Antarctic Circumpolar Current has warmed faster than the global ocean as a whole. If these processes continue, ocean acidification will further increase, alien species will be more successful invading Antarctic waters, and there will be major changes in the polar food web and biodiversity (Turner et al. 2009).

The review also warns that the ozone hole is going to disappear over this century due to measures taken by man, which will transfer the effects of greenhouse gas increases fully onto the Antarctic continent, which could warm by as much as $3^{\circ} \mathrm{C}$ until 2100. Winds in the Southern Ocean are expected to strengthen further, and sea ice will decrease by a third. The temperature increase on the continent will not be sufficient to melt the main ice sheet on East Antarctica; increasing snowfall may even reduce sea level rise. Contrarily, the West Antarctic ice sheet will lose substantial quantities of ice, which will contribute to a projected total sea level rise due to global warming of 1.4 metres.
Can biotic climate change effects be distinguished at this early stage?

Despite the fact that at this time, warming in high latitudes of the southern hemisphere is still proceeding at a slower rate than in the Arctic, where some effects are quite dramatic (Hassol 2004), consequences have been reported for the Antarctic Peninsula, the maritime Antarctic and the Magellan region. However, much information is soft, and in many cases the impact of regional warming is difficult to distinguish from other impacts such as the effects of fishing, perturbation by tourism etc.

At the present rate of ocean acidification, diatom shells are already deformed (Wolf-Gladrow pers.comm.), pteropods will not survive after 2100 , with serious consequences for the marine food web (Orr et al. 2005), and cold water corals, echinoderms and other fauna with calcified skeletons are endangered (WBGU 2008).

West Antarctica has warmed slightly, and the eastern coast of the Antarctic Peninsula has shown rapid summer warming, caused by the stronger westerly winds bringing warm, moist air from the ocean (Turner et al. 2009). A switch from snowfall to rain in summer has resulted in an expansion of microbial, plant and animal communities in newly available land. In addition, it favours the success of "aliens" introduced by man. The retreat of $90 \%$ of the Antarctic Peninsula's glaciers, together with increasing sediment load, turbidity and iceberg scour has led to faunal shifts in some areas. Off the Fourcade glacier in the Potter Cove, South Shetland Islands, dense populations of ascidians (Fig. 4) are now covering vertical walls formerly concealed by the glacier ( $\mathrm{R}$. Sahade pers. comm.). We do not know whether the ascidians colonized these areas after the retreat of the glacier or were living underneath before.

Declining sea ice presence west of the Antarctic Peninsula has affected the food web. Antarctic krill (Euphausia superba) have dramatically declined, probably due to a decrease of winter ice. Krill feed on algae on the underside of the ice (Marschall 1988). Today's stocks are estimated to be only one-fifth of those 30 years ago (Atkinson et al. 2004). Salps have increased simultaneously. Crystal krill E. crystallorophias may be favoured by greater persistence and size of coastal polynyas but cannot make up for the losses in E. superba (Siniff et al. 2008). It is not 


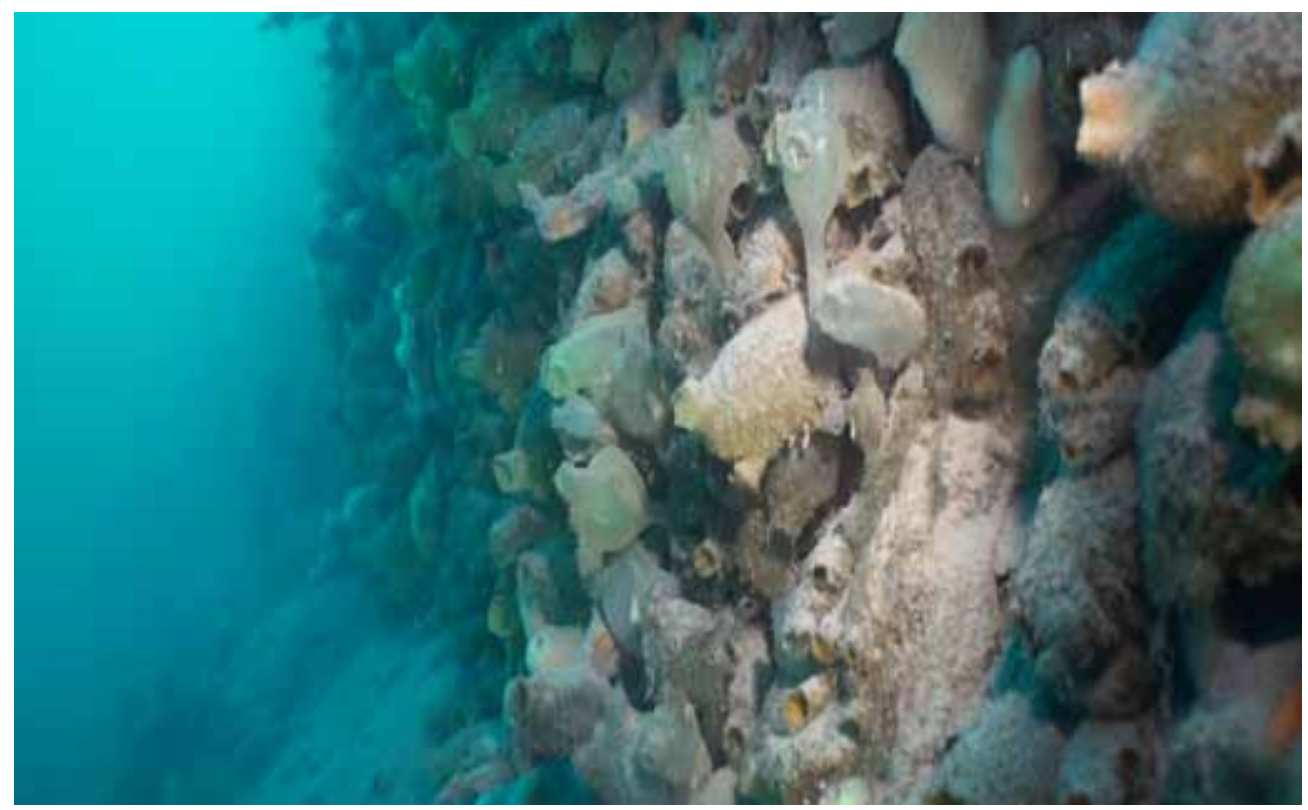

Fig. 4. Dense ascidian populations at the Fourcade Glacier (Potter Cove, South Shetland Islands) Photo: R. Sahade.

clear to what extent penguins and seals can easily switch to other food such as fish and squid; only in the case of Weddell seals fish are staple food locally (Plötz et al. 2001).

Changes in extent, persistence and type of pack ice affect Weddell and crabeater seals most, whereas they favour fur and elephant seals (Siniff et al. 2008). In Signy Island, the exploding fur seal population has led to severe eutrophication and destruction of the vascular vegetation (Quayle et al. 2003). In late 2000 a large portion of the Ross Iceshelf broke off and blocked the advection of sea ice from McMurdo Sound until winter 2006. As a result, the fast ice increased in extent, thickness, and seasonal persistence. Weddell seals were directly affected by this "natural experiment" (Siniff et al. 2008), supposedly from increased fast ice thickness, which closed off cracks predictably present in previous years.

Distribution and abundance of penguins has undergone a fundamental reorganization in the Scotia Sea and at the Antarctic Peninsula (Smith et al. 1999). Adelies, which need winter pack ice, have declined, and chinstraps have taken their breeding sites. Interestingly, adelies have occupied this area for $>600$ years whereas chinstraps appeared only 50 years ago. Both species and gentoo penguins are forced further south. On the other hand, king penguins, which feed on myctophids, seem to be in good shape everywhere (Woehler \& Croxall 1997). Emperors, contrary to other penguin species, take advantage of less sea ice in winter if their breeding sites on fast ice persist, because this leads to shorter feeding migrations (Croxall et al. 2002).

\section{Some fields and goals of future cooperation}

Abiotic background: importance

for evolution of Antarctic life

The abiotic background of plate tectonics, continental breakup, ocean gateway opening, formation of the Antarctic Circumpolar Current (ACC) and glaciations is of utmost importance for biologists studying the evolution of the Antarctic fauna. Unfortunately, the literature is often contradictory; especially in the case of gateway opening, where dates between 50 and $15 \mathrm{Ma}$ can be found in the literature, and where there is not even consensus whether the Tasman gateway or Drake Passage opened first. Clearly, continents do not drift apart overnight, so part of the confusion may arise from the fact that some authors refer to the onset of opening whereas others talk about the late phase, when continents were separated by deep sea, allowing a vigorous flow of the ACC (see Lyle 
et al. 2007 for a recent contribution). It is clear, too, that much information in the Drake Passage is swallowed because it is a subduction zone. For evolutionary biologists it makes a great difference whether the Drake Passage allowed a vigorous flow of the ACC 40 or $15 \mathrm{Ma}$ ago, whether the Tasman gateway opening preceded that of Drake Passage, or whether the Antarctic icecap reached its present extension 40 or $10 \mathrm{Ma}$ ago. For these questions we need close cooperation across disciplines (no more parallel sessions at SCAR meetings!). Recent progress in molecular genetics enables biologists to take an active part in the discussion rather than "adapting" their molecular data, e.g. for the separation of closely related species, to the date in the literature that fits them best.

\section{Biological heritage of the past}

The biological heritage of the past goes back to Gondwana times in some cases of relict species, but also reflects glaciation of Antarctica and the Magellan region, climate change, dispersal by currents, immigration and emigration. There are great differences among taxa concerning faunal and floral similarities between the remnants of Gondwana. Generally the faunal overlap is fairly high between the Magellan region, the Scotia Arc and the Antarctic Peninsula, often on genus and sometimes on species level, but low between the Antarctic/the Magellan region and Australia/New Zealand. This might indicate an earlier opening of the Tasman gateway, however it could also reflect major Indopacific influences in Australia. In this case, cooperation is required between biologists working on different continents, including traditional taxonomists and those applying modern methods such as genetic barcodes to arrive at evolutionary trees.

It seems clear now that it was not the $\mathrm{K} / \mathrm{T}$ transition but Middle Eocene cooling about $40 \mathrm{Ma}$ ago, that caused major extinctions in the Antarctic fauna, although an icecap of today's dimensions may have existed only $10 \mathrm{Ma}$ (Berger 2009). Unfortunately much of the fossil evidence is buried under ice, with few exceptions such as Seymour Island where the Eocene changes can be studied (Crame \& Rosen 2002, Aronson et al. 2007). There are basically six alternatives for the origin of the present Antarctic fauna (e.g. Sieg 1992): Gondwana relicts (in situ, endemic), deep sea-shallow migrations and the reverse, immigration/emigration via the Scotia Arc, and dispersal of pelagic or drift stages by currents and eddies. Sometimes closely related species of a taxon have taken different routes. A special case are the eurybathic species in the high Antarctic benthos, which probably submerged when the icecap increased and recolonized the shelf when the ice retreated (Brey et al. 1996); however, there were other processes of emergence and submergence involved, too (Brandt 2000). The study of the origin of the Antarctic fauna requires close cooperation between taxonomists, molecular geneticists and palaeontologists.

Another interesting question is to what extent continental breakup has led to latitudinal gradients in community parameters, species properties etc. No global latitudinal clines exist in species richness, abundance and biomass, and the famous "bell-shaped curve" of species richness often discussed in the literature is not valid for the southern hemisphere (Clarke 1992, Gray 2001) except for certain taxa such as decapod crustaceans (Arntz et al. 2005). In fact, a number of taxa are particularly speciose in the South Polar Sea and show increasing species numbers from the Magellan Province towards the Antarctic; examples are pycnogonids, isopods, amphipods and sponges (Clarke \& Johnston 2003). Latitudinal clines do exist in fecundity, developmental time, first maturity and growth, as is evident from a retardation of these parameters in most species toward the pole (e.g., Gorny et al. 1992, Arntz et al. 1992, 2005, Peck 2001). Polar marine invertebrates and fish have lower activity rates and limited upper temperature tolerance (Peck 2001, Pörtner et al. 2005). All these characteristics make them vulnerable to continued warming conditions (Barnes \& Peck 2008). Brooding and larval lecitotrophy are common, planktotrophic larvae are rare (Arntz \& Gili 2001, Arntz et al. 2005), but those species with pelagic planktotrophic larvae belong to the commonest invertebrates in shallow water, leading Poulin et al. (2002) to the hypothesis that this might be an adaptation to recent conditions. The archaic aspect of the three-dimensional epibenthic communities in the high Antarctic (Gili et al. 2006), on the other hand, does not seem to originate from direct descendence but rather from convergent environmental and biotic conditions (lacking riverine input, low turbidity, lack 
of predators feeding on hard substances (Aronson \& Blake 2001, Gili et al. 2006, Aronson et al. 2007). Many of the sessile suspension feeders in these communities seem to prefer tiny food particles available year-round (Clarke \& Leakey 1996) to the rain of larger particles generated during the short high primary production phase in summer (Orejas et al. 2001), a behaviour that may have originated during the ice age, when the sea surface remained frozen and food was advected over large distances, as is the case under the ice shelves today. The themes presented in this paragraph need cooperation of ecologists, physiologists, taxonomists and palaeontologists.

Biotic distribution and faunal exchange

Drake Passage and the Scotia Sea with the Scotia Arc are key areas for many events that have shaped recent biota on the Antarctic Peninsula and in the Magellan region. The idea of total isolation of Antarctica and the waters surrounding it by the ACC with the Polar Front, which dominated the literature for a long time, has changed to some extent in view of recent finds. Obviously this barrier is somewhat "porous" (Clarke et al. 2006b) especially in interglacial periods like the present one, and regional warming clearly contributes to exchange, because it reduces the temperature differences between the waters to the north and south of the Polar Front.

Circumantarctic transport by the powerful ACC is obviously much easier than perpendicular transport into and out of Antarctic waters. W-E transport is easier than the contrary due to the West Wind Drift, although the Weddell Gyre and the East Wind Drift close to the continent may provide return mechanisms. Fauna and flora can be distributed by dispersal of larvae, drift stages and asexual propagules (e.g., from budding; Teixidó et al. 2006) but also by rafting on macroalgae, pumice or driftwood (Thiel \& Gutow 2004). Larval or drift stage dispersal is more successful in cold water, because the duration of larval life is extended (Aronson et al. 2007), however a long larval life in clear water is also dangerous (Arntz et al. 2005). For a long time the idea of a predominantly circumpolar Antarctic marine fauna prevailed in the literature, but the many finds of cryptic species due to the use of molecular genetics (see, e.g., Held 2003, Held \&
Wägele 2005 for isopods) are challenging this idea. Presently the taxonomic confusion is great, at least for non-taxonomists, because sometimes species of the same family, despite identical modes of reproduction and larval life, become cryptic new species or reveal gene flow. Examples can be found among the serolid isopods, all of them brooders (Brandt pers. comm.). Septemserolis septemcarinatus, a shallow-water isopod living on South Georgia, Bouvet Island and Marion Island, has maintained its genetic identity despite isolation by vast deep-sea areas (Leese et al. 2010). The islands and shallows of the Scotia Arc seem to function as stepping stones, although deep-sea areas in between, strong currents and unfavourable bottoms for larval settlement (pumice, lava) certainly provide obstacles. The northern branch of the Scotia Arc is faunistically more magellanic, the southern branch more Antarctic (Arntz et al. 2005).

Considering the relative temperature constancy of South Polar Sea waters, the Polar Front (PF) with its sudden decline of several degrees appears as a barrier. In fact regional faunal similarities and endemism are much higher inside the PF than around other continents (Griffiths et al. 2009), which, of course, is also a consequence of the lack of major latitudinal clines around Antarctica, contrary to the conditions around other continents. There are differences; for example, the deep sea is up to $2^{\mathrm{a}} \mathrm{C}$ warmer than the shelf at high latitudes, but up to $2^{\mathrm{a}} \mathrm{C}$ colder than the shelf at the Subantarctic islands (Clarke et al. 2009); the Bellingshausen Sea is generally warmer, the high Antarctic Weddell Sea and Ross Sea are colder than most other areas around the continent. Does this challenge the old paradigm of Lipps \& Hickman (1982) that exchange via the deep sea is easy for pressure-resistant fauna because of similarly deep temperatures? The evidence is contradictory.

On the one hand, brachyuran decapods - which are quite speciose in the Magellan region - have not been able to invade Antarctic waters since they got extinct by Eocene cooling, and Lithodid crabs have not yet conquered the high Antarctic shelf (Arntz \& Gorny 1991, Thatje et al. 2005). On the other hand, "warm deep water" often creeps up the slope of the Eastern Weddell Sea (Arntz et al. 1992), where the rich benthic epifauna does not seem to be influenced. After all, there are differences in temperature tolerance between species (Peck 2001; Frederich et al. 2001; Poertner et al. 2005), which 


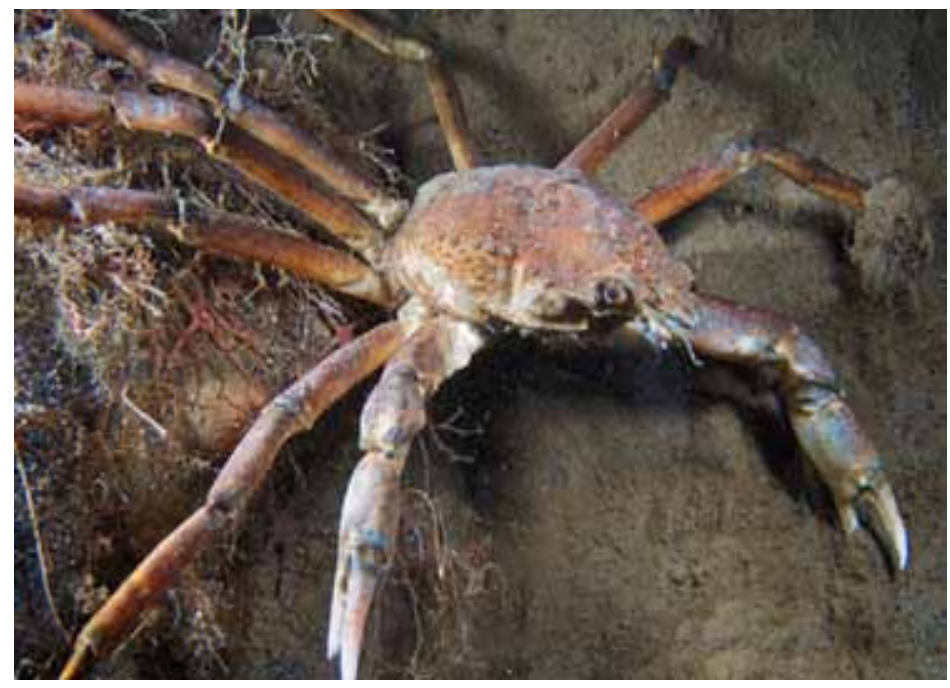

Fig. 5. Hyas araneus - an alien species invading Antarctic waters?

may facilitate or impede exchange. In the long term, the question arises whether the PF will persist if continued warming affects the downwelling of cold water around the Antarctic continent.

A potential invader from cold northern hemisphere waters will have problems to cross tropical regions in ballast water or as a fouling organism on a ship`s hull (Gollatsch et al. 1999), and for any invader it is difficult to penetrate the barrier of the Polar Front, which may, however, occur in an eddy of the ACC as it happens in other fronts (Glorioso et al. 2005). However, even if they succeed to cross the PF, another problem is survival. Until quite recently, the temperature differences seem to have impeded successful colonization, but recent finds of live brachyuran larvae (Thatje \& Fuentes 2003) and an adult couple of the North Atlantic spider crab Hyas araneus (Tavares \& Melo 2004) at the South Shetlands may indicate a beginning change (Fig. 5).

In fact the Antarctic Peninsula, with the highest incidence of human activities in the Antarctic, is the most likely place for invasions (Clarke et al. 2009). Successful invasion and colonization of "aliens", especially of durophagous predators such as brachyuran decapods and certain fish, and an extension of the lithodid decapods to the high Antarctic shelf may have devastating effects on the Antarctic fauna, which since the Eocene had no need to maintain or evolve hard skeletons. Due to the added costs of depositing $\mathrm{CaCO}_{3}$ in cold water, most mollusks, corals etc. are thin-shelled in the
Antarctic, which would make them an easy prey (Aronson et al. 2007).

It is obvious that biotic distribution and faunal exchange is a very important theme in Antarctic research, with major implications for the Magellan region both as a donor to and recipient of Antarctic biota. This field requires in the first line the cooperation of ecologists, physiologists, evolutionary biologists and physical oceanographers.

\section{Ice and biota}

Ice in its different forms is of utmost importance for marine life from microorganisms to seals and penguins, and for all kind of energy processes. The floating margins of continental ice caps cover large areas with deep-sea affinities, which do not receive the particle rain of primary production directly from the surface but via long ways of advection from ice free areas. The benthic fauna beneath the ice shelves is favoured by their disruption as additional shallow-water areas are uncovered and productivity there is increased. A recent survey of the Larsen embayments, where in 1995 and 2002 the ice shelf collapsed dramatically, evidenced that under the formerly oligotrophic ice-shelf-covered conditions a macro- and megabenthic community occurred, which is typical also of non-ice-shelf covered Antarctic seafloor. It included sessile filter feeders such as hexactinellid sponges, cnidarians and ascidians, however impoverished in species richness, density 
and biomass as compared to the SE Weddell Sea shelf (Gutt et al. 2010). Surprisingly also 16 representatives of deep-sea taxa, mainly echinoderms, were found, the occurrence of which may reflect the former ice-covered oligotrophic conditions. On the other hand, ice shelf breakup in some areas increases the amount of icebergs and growlers scouring the seafloor. The impacts of this perturbation have been studied in the southeastern Weddell Sea (Gerdes et al. 2003), arriving at the surprising result that at the present rate of scouring, despite local destruction of the benthos, benthic diversity on a regional scale is enhanced (Gutt \& Piepenburg 2003). This result, which has an interesting parallel in the shift of terrestrial vegetation zones caused by warming in northern Chile (Mary Kalin, this Colloquium), is in accordance with the Intermediate Disturbance Hypothesis of Connell (1978). At this time we do not know, at which point of warming and increased iceberg scour benthic diversity will respond negatively. Off the western Antarctic Peninsula, where - like in other parts of the Antarctic - icebergs and growlers are locked into position by winter sea ice, shrinking winter ice has already increased iceberg scour (Smale et al. 2008).
Studies of Antarctic pack ice, which for a long time was considered to be almost devoid of life except for a couple of seals and penguins, have revealed a great diversity of life forms in the channel system within the ice and underneath the floes (Spindler \& Dieckmann 1994, Gradinger 1995, Thomas \& Dieckmann 2003). Although many of these species live in permanent exchange between the ice and the water column, a significant shortening of the ice cover or total disappearance of the pack would threaten their existence. It would also have strong impacts on life in the water column and at the seafloor, because krill, copepods, fish and many other organisms depend on the sea ice for food and protection. Melting sea ice in spring stimulates processes in the water column and at the seafloor (Isla et al. 2009). Penguins and seals use pack and fast ice for haul out, protection against predators, for weaning their young and for moulting. All in all, there is a severe threat that a whole ecosystem might disappear due to warming; a process that is proceeding at an even faster rate in the Arctic (Gradinger 1995). We may not be able to stop this development, but it should be studied in close cooperation between sea ice ecologists,

\section{Time scales of recovery?}

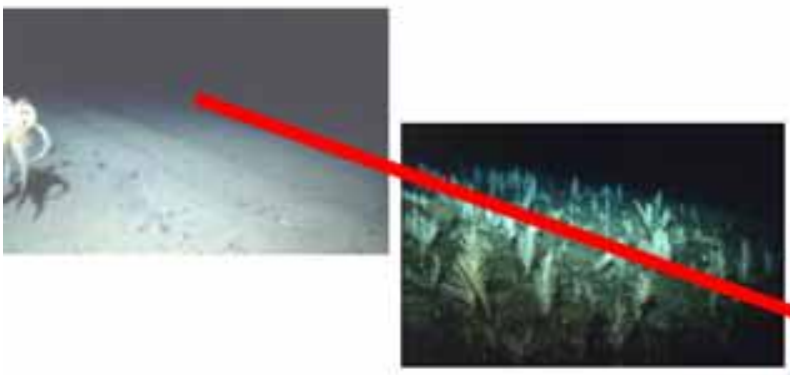

phase 1 ?

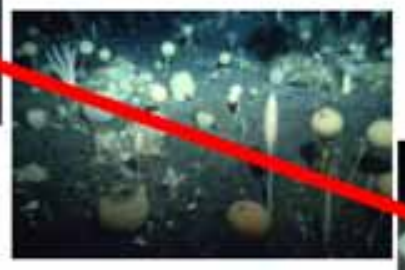

phase 2 ?

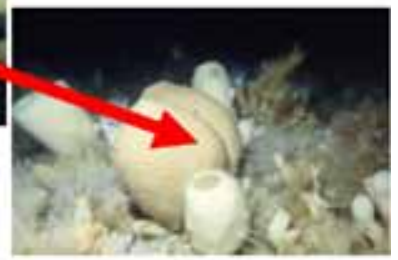

\section{Suggested phases of succession}

Fig. 6. Grounding icebergs destroy benthic shelf communities and create space for enhanced regional diversity (after Knust et al. 2003). The time scales of recovery are not yet fully understood, and there may be alternatives for the different phases of succession. 
planktologists, fish, seal and bird ecologists and glaciologists.

There is no doubt that many more research themes related to climate change exist, where marine and polar scientists from different disciplines, institutions and countries can collaborate. Few fields require such an amount of cooperation, and there is hardly any other field where the tasks are similarly widespread and voluminous, so that they cannot be tackled by individual efforts. SCAR and other organizations are providing the coordination frame, vessels like "Polarstern" and many stations the adequate platforms, and many universities and research institutions the theoretical background for cooperation. It is up to the Magellan region to use these instruments, and to take advantage of its favourable regional position in the global process of climate change.

Some specific suggestions to improve Magellan participation in climate change programmes

All the research themes presented in this paper, and probably many others, have in common that they cannot be tackled successfully by a single country, region or institute. National and international cooperation is required, offering great opportunities to those institutes situated in areas such as the Magellan region, where access to the Antarctic is easy and important changes are occurring. Global and regional climate change puts the Magellan region in the centre of interest and offers multiple opportunities for cooperative research. The move of INACH to Punta Arenas has increased the critical mass, so there is a chance that a regional hotspot of coldwater research will develop in the Cono Sur. However, to be an active member of the scientific community, links to many national and international institutions have to be intensified. In the first line this is true for SCAR and the programmes associated to it (EBA, CAML, MarBIN) because SCAR is the main coordinator of climate-related research in Antarctic and Subantarctic regions. Participation of experts in SCAR meetings, symposia and scientific groups is a prerequisite to be informed about ongoing polar research. An intense exchange with polar institutes worldwide would be helpful in many respects: scientists travelling to and from the Antarctic could be invited to give lectures and short courses, Chilean scientists could embark on foreign vessels or work at foreign stations, master and doctorate students could write their theses abroad, young scientists could be trained in methods and procedures of polar research at foreign institutes or onboard foreign vessels. A positive side effect would be an improvement of language capabilities of Chileans, particularly the dominance of English as the main scientific language. It may be necessary to install a major unit at UMAG/INACH to take care of all these international affairs; the present Dirección de Programas Antárticos y Subantárticos-UMAG might be the centre, but it is too small and has too many other tasks to do this job successfully.

Exchange should be intensified also with other institutions in Patagonia and Tierra del Fuego, such as the CADIC and CENPAT in Ushuaia and Puerto Madryn/Argentina or the CIEP in Coyhaique. As Magellanic research is logistically much easier and also cheaper than Antarctic research, many projects especially under the IBMANT umbrella might be initiated in the Magellan region and later be transferred into the Antarctic. This could happen in the frame of a newly designed programme "Climate Change and its Consequences in the Cold", which should be funded partly by the Intendencia of the XII Región and might also convince the CONICYT to increase funding of research in the Cono Sur and the Antarctic. Along the same line, INACH and UMAG should make an effort to organize a third IBMANT conference in a wider context, integrating also non-biological groups such as the geologists around Francisco Hervé at the Universidad de Chile and representatives of physical oceanography and meteorology. A cold-region research nucleus at Punta Arenas, combining efforts with the CADIC in Ushuaia and other institutes, could take a lead in studies on past and recent climate change and the biological consequences of these processes. After all, no other area in the southern hemisphere is closer to the region where drastic climate change occurs!

Better use should be made of the Chilean bases on the Antarctic Peninsula. Several decades ago, Chile was a leader in Antarctic biological research, and the best scientists were keen to do research on the Antarctic biota. In view of the ongoing difficulties with national research vessels and the enormous dimensions of the Chilean Pacific coast it is understandable that most universities and 
institutes restrict their efforts to the mainland, but exactly this situation offers great opportunities for the UMAG and the Cono Sur institutes. Even if no national research ship is available for the Antarctic, Chilean logistics can transport researchers by air, and work at the Frey base can be done by diving and using zodiacs as it is done at Teniente Jubany. In this context, the UMAG should support a scientific diving group, which will find good working conditions also in the surroundings of Punta Arenas, Puerto Natales and in the inland seas (Seno Otway, Seno Skyring).

UMAG should also invest in a small motor launch that can be manoevered by a single person to work in the Straits of Magellan, the inland seas and the Beagle Channel. With such a small vessel, biological and physical work could be done, monitoring stations could be established, material and data for thesis work be obtained and small groups of students could be trained. The university should not depend exclusively on the availability of larger national research vessels, which allow only occasional sampling and do not permit the establishment of a routine programme, time series and similar work, which is fundamental for decent science.

\section{LITERATURE CITED}

Arntz, W.E. \& A. Clarke (eds.) 2002. Ecological Studies in the Antarctic Sea Ice Zone: Results of EASIZ Midterm Symposium. Springer, Berlin: 277 pp.

Arntz, W.E. \& J.M. Gili 2001. A case for tolerance in marine ecology: Let us not put out the baby with the bathwater. Scientia Marina, 65(2):283-299

Arntz, W.E. \& M. Gorny 1991. Shrimp (Decapoda, Natantia) occurrence in the eastern Weddell Sea. Polar Biology, 11(3):169-177

Arntz, W.E. \& C. Ríos 1999. Magellan-Antarctic: Ecosystems that Drifted Apart. Scientia Marina, 63(1):518 pp.

Arntz, W.E., G.A. Lovrich \& S. Thatje (eds.), 2005. The Magellan-Antarctic Connection: Links and Frontiers at Southern High Latitudes. Scientia Marina, 69(2):373 pp.

Arntz, W.E., T. Brey, D. Gerdes, M. Gorny, J. Gutt, S. Hain \& M. Klages 1992. Patterns of life history and population dynamics of benthic invertebrates under the high Antarctic con- ditions of the Weddell Sea. In: Colombo, G., I. Ferrari, V.U. Ceccherelli \& R. Rossi (eds.), Marine Eutrophication and Population Dynamics. Olsen \& Olsen, Fredensborg: 221-230 Arntz, W.E., S. Thatje, D. Gerdes, J.M. Gili, J. Gutt, U. Jacob, A. Montiel, C. Orejas \& N. Teixidó 2005. The Antarctic-Magellan connection: macrobenthos ecology on the shelf and upper slope, a progress report. Scientia Marina, 69 (2):237-269

Aronson, R.B. \& D.B. Blake 2001. Global climate change and the origin of modern benthic communities in Antarctica. American Zoology, 41:27-39

Aronson, R., Thatje S., Clarke A., Peck L.S., Blake D.B., Wilga C.D. \& B.A Seibel 2007. Climate change and invasibility of the Antarctic benthos. Annual Review of Ecology, Evolution, and Systematics, 38:129-154

Atkinson, A., V. Siegel, E. Pakhomov \& P. Rothery 2004. Long-term decline in krill stock and increase in salps within the Southern Ocean. Nature, 432:100-103

Barnes, D.K.A., 2005. Changing chain: past, present and future of the Scotia Arc's and Antarctica's shallow benthic communities. Scientia Marina, 69 (2):65-89

Barnes, D.K.A. \& L.S. Peck 2008. Vulnerability of Antarctic shelf biodiversity to predicted regional warming. Climate Research, 37:149-163

Berger, W.H., 2009. Ocean. Reflections on a Century of Exploration. University California Press, Berkeley, 519 pp.

Brandt, A., 2000. Hypotheses on Southern Ocean peracarid evolution and radiation (Crustacea, Malacostraca). Antarctic Science, 12:269-275

Brandt, A. \& B. Hilbig (eds.), 2004. ANDEEP (ANtarctic benthic DEEP-sea) biodiversity: colonization history and recent community patterns: a tribute to Howard L. Sanders. Deep Sea Research II, 51:1457-1920

Brey, T., C. Dahm, M. Gorny, M. Klages, M. Stiller \& W. E. Arntz 1996. Do Antarctic invertebrates show an extended level of eurybathy? Antarctic Science, 8:3-6

CAML (Census of Antarctic Marine Life), 2009. Renewal proposal (2009-2010) submitted by SCAR to the Alfred P. Sloan Foundation (mimeo). 
Clarke, A., 1992. Is there a diversity cline in the sea? Trend in Ecology and Evolution, 9:286 f.

Clarke, A. \& N.M. Johnston 2003. Antarctic marine benthic diversity. Oceanography and Marine Biology, An Annual Review, 41:47-114

Clarke, A. \& R.J.G. Leakey 1996. The seasonal cycle of phytoplankton, macronutrients, and the microbial community in a nearshore Antarctic marine ecosystem. Limnology and Oceanography, 41:1281-1294

Clarke, A., W.E. Arntz \& C. Smith (eds.), 2006a. EASIZ: Ecology of the Antarctic Sea Ice Zone. Deep Sea Research, II: 803-1140.

Clarke, A., D.K.A. Barnes \& D.A. Hodgson 2006 b. How isolated is Antarctica? Trend in Ecology and Evolution, 20: 1-3

Clarke, A., E.J. Murphy, M.P. Meredith, J.C. King, L.S. Peck, D.K.A. Barnes \& R.C. Smith 2007. Climate change and the marine ecosystem of the western Antarctic Peninsula. Philosophical Transactions of the Royal Society, London B 362:149-166.

Clarke, A., H.J. Griffiths, D.K.A. Barnes, M.P. Meredith \& S.M. Grant 2009. Spatial variation in seabed temperatures in the Southern Ocean: Implications for benthic ecology and biogeography. Journal of Geophysical Research 114, G03003, doi: 10.1029/2008JG000886.

Connell, J.H. (1978) Diversity in tropical rain forests and coral reefs. Science, 199:1302-1309

Cook, A., A. Fox, D. Vaughan \& J. Ferrigno 2005. Retreating glacier fronts on the Antarctic Peninsula over the past half-century. Science, 308:541-544

Crame, J.A. \& B.R. Rosen 2002. Cenozoic palaeogeography and the rise of modern biodiversity patterns. In: Crame, J.A. \& A.W. Owen, Palaeobiogeography and biodiversity change: the Ordovician and Mesozoic-Cenozoic Radiations. Geological Society, London: 153-168

Croxall, J.P., P.N. Trathan \& E.J. Murphy 2002. Environmental change and Antarctic seabird populations. Science 297:1510-1514

Cullen, J.J. \& P.J. Neale 1994. Ultraviolet radiation, ozone depletion, and marine photosynthesis. Photosynthesis Research 39:303-320

Diffey, B.L., 1992. Stratospheric ozone depletion and the risk of non-melanoma skin cancer in a British population. Physics in Medicine and Biology 37:2267-2279

El-Sayed, S.Z. 1994. Southern Ocean Ecology: The BIOMASS Perspective. Cambridge University Press, Cambridge

Farman, J.C., B.G. Gardiner \& J.D. Shanklin 1985. Large losses of total ozone in Antarctica reveal seasonal $\mathrm{C} 10 \mathrm{x} / \mathrm{NOx}$ interactions. Nature 315:207-210

Frederich, M., F.J. Sartoris \& H.O. Pörtner 2001. Distribution patterns of decapod crustaceans in polar areas: a result of magnesium regulation? Polar Biology 24:719-723

Gallardo, V.A., O. Ferretti \& H.I. Moyano (eds.) 1992. Oceanografia en Antártica. Ediciones Documentadas, Santiago

Gerdes, D., B. Hilbig \& A. Montiel 2003. Impact of iceberg scouring on macrobenthic communities in the high-Antarctic Weddell Sea. Polar Biology 26:295-301

Gili, J.M., W.E. Arntz, A. Palanques, C. Orejas, A. Clarke, P. K. Dayton, E. Isla, N. Teixidó, S. Rossi \& P.J. López-González 2006. A unique epibenthic assemblage of sessile suspension feeders with archaic features in the high-Antarctic. Deep Sea Research. II 53: 1029-1052

Glorioso, P.D., A.R. Poila \& R.R. Leben 2005. Mesoscale eddies in the Subantarctic Front - Southwest Atlantic. Scientia Marina 69(2):7-15

Gollatsch, S., D. Minchin, H. Rosenthal \& M. Voigt 1999. Exotics across the Ocean: Case Histories of Introduced Species. Logos, Berlin.

Gorny, M., W.E. Arntz, A. Clarke, \& D.J. Gore 1992. Reproductive biology of caridean decapods from the Weddell Sea. Polar Biology 12:111-120

Gradinger, R. 1995. Climate change and biological oceanography of the Arctic Philosophical Transactions of the Royal Society London (A) 352:277-286

Gray, J. 2001. Antarctic marine benthos biodiversity in a world-wide latitudinal context. Polar Biology 24:633-641

Griffiths, H.J., D.K.A. Barnes \& K. Linse 2009. Towards a generalized biogeography of the Southern Ocean benthos. Journal of Biogeography 36:162-177 
Gutt, J. \& D. Piepenburg 2003. Scale-dependent impact on diversity of Antarctic benthos caused by grounding of icebergs. Marine Ecology Progress Series 253:77-83

Gutt, J. , Barratt, I., Domack, E., dðUdekem dðAcoz, C. Dimmler, W., Grémare, A., Heilmayer, O., Isla, E., Janussen, D., Jorgensen, E., Kock, K., Lehnert, L., López-Gonzáles, P., Langner, S., Linse, K., Manjón-Cabeza, M., Meißner, M., Montiel, A., Raes, M., Robert, H., Rose, A., Sañé Schepisi, E., Saucède, T., Scheidat, M., Schenke, H., Seiler, J. and Smith, C. 2010. Biodiversity change after climate-induced ice-shelf collapse in the Antarctic. Deep Sea Research II, 58(1): 74-83

Hassol, S.J., 2004. Impacts of a Warming Arctic. Cambridge University Press, Cambridge.

Held, C., 2003. Molecular evidence for cryptic speciation within the widespread Antarctic crustacean Ceratoserolis trilobitoides (Crustacea, Isopoda). In: Huiskes, A.H., W.W. Gieskes, J. Rozema, R.M. Schorno, S.M. van der Vies \& W.J. Wolff (eds.), Antarctic Biology in a Global Context. Backhuys Publ., Leiden: 135-139

Held, C. \& J.W. Wägele 2005. Cryptic speciation in the giant Antarctic isopod Glyptonotus antarcticus (Isopoda: Valvifera: Chaetiliidae). Scientia Marina 69(2):175-181

Hempel, G. (ed.), 1993. Weddell Sea Ecology. Results of EPOS European "Polarstern" Study. Springer, Berlin: $333 \mathrm{pp}$.

Hofmann, E., P.H. Wiebe, D.P. Costa, and J.J. Torres, 2004. An overview of the Southern Ocean Global Ocean Ecosystems Dynamics program. Deep Sea Research II, 51:1921-1924

Hofmann, E.E., D.P. Costa, K. Daly, M.S. Dinniman, J.M. Klinck, M. Marrari, L. Padman \& A. Piñones 2009. Results from US Southern Ocean GLOBEC synthesis studies. GLOBEC International Newsletter. 15:43-48

IPCC (Intergovermental Panel on Climate Change), 2007. Climate change 2007: impacts, adaptations, and vulnerability. $4^{\text {th }}$ Assessment Report. Cambridge University Press, Cambridge.

Isla, E., D. Gerdes, A. Palanques, J.-M. Gili, W.E. Arntz \& G. König-Langlo 2009. Downward particle fluxes, wind and a phytoplankton bloom over a polar continental shelf: A stor- my impulse for the biological pump. Marine Geology 259:59-72

Knust, R., W.E. Arntz, M. Boche, T. Brey, D. Gerdes, K. Mintenbeck, A. Schröder, A. Starmanns and N. Teixido, 2003. Iceberg scouring on the Eastern Weddell Sea shelf (Antarctica): a benthic system shaped by physical disturbance. In: Antarctic Biology in a Global Context. Huiskes, A.H.L., W.W.C. Gieskes, J. Rozema, R.M.L. Schorno, S.M. van der Vries \& W.J. Wolff, eds. Backhuys Publishers, Leiden: 96-101

Lamy, F., J. Kaiser, U. Ninnemann, D. Hebbeln, H.W. Arz \& J. Stoner 2004. Antarctic timing of surface water changes off Chile and Patagonian icesheet response. Science 304:1959-1962

Leese, F., S. Agrawal \& C. Held 2010. Long-distance island hopping without dispersal stages: transportation across major zoogeographic barriers in a Southern Ocean isopod. $\mathrm{Na}$ turwissenschaften 97:583-594

Lipps, J.H. \& C.S. Hickman 1982. Origin, age and evolution of Antarctic and deep-sea faunas. In: Ernst, W.G. \& J.G. Morin (eds): The Environment of the Deep Sea. Vol.2. Prentice Hall Inc., Englewood Cliffs, N.J., 325-356.

Lyle, M., S. Gibbs, T.C. Moore \& D.K. Rea 2007. Late Oligocene initiation of the Antarctic Circumpolar Current: Evidence from the South Pacific. Geology 35:691-694

Marschall, H.P., 1988. The overwintering strategy of Antarctic krill under the pack-ice of the Weddell Sea. Polar Biology 9:129-135

Meredith, M.P. \& J.C. King 2005. Rapid climate change in the ocean west of the Antarctic Peninsula during the second half of the $20^{\text {th }}$ century. Geophysical Research Letters $32 \mathrm{vol}$. L19604, 5 pp. doi:10.1029/2005GL024042 Mutschke, E., C. Ríos \& M. Gorny 1999. Estudio bentónico en fiordos y canales patagónicos y fueguinos (CIMAR-FIORDO). Informe de Crucero. Comité Oceanográfico Nacional, Concepción: 72-85.

Obermüller, B., S. Puntarulo \& D. Abele 2007. UV-tolerance and instantaneous physiological stress responses of two Antarctic amphipod species Gondogeneia antarctica and Djerboa furcipes during exposure to UV radiation. $M a-$ rine Environmental Research, 64(3):267-285 
Orejas, C., J.-M. Gili, P.J. López-González \& W.E. Arntz 2001. Feeding strategies and diet composition of four Antarctic cnidarian species. Polar Biology 24:620-627

Orr, J.C., V.J. Fabry and 25 further co-authors 2005. Anthropogenic ocean acidification over the twenty-first century and its impact on calcifying organisms. Nature 437:681-686

Peck, L., 2001. Ecophysiology of Antarctic marine ectotherms: limits to life. Polar Biology 25:31-40

Plötz, J., H. Bornemann, R. Knust, A. Schröder \& M. Bester 2001. Foraging behaviour of Weddell seals, and its ecological implications. Polar Biology 24:901-909

Pörtner, H.O., D. Storch \& O. Heilmayer 2005. Constraints and trade-offs in climate-dependent adaptation: energy budgets and growth in a latitudinal cline. Scientia Marina 69 suppl.2:271-285

Poulin, E., A.T. Palma \& J.-P. Féral, 2002. Evolutionary versus ecological success in Antarctic benthic invertebrates. Trend in Ecology and Evolution 17:218-222

Quayle, W.C., L. Peck, H. Peat, J.C. Ellis-Evans \& P.R. Harrigan, 2002. Extreme responses to climate change in Antarctic lakes. Science 25:645

Rack, W. \& H. Rott 2004. Pattern of retreat and disintegration of the Larsen B ice shelf, Antarctic Peninsula. Annals of Glaciology 39:505-510

Rott, H., P. Skvarca \& T. Nalger 1996. Rapid collapse of northern Larsen ice shelf, Antarctica Science, 271:788-792

Sieg, J., 1992. On the origin and age of the Antarctic Tanaidacean fauna. In: Gallardo, V.A., O. Ferretti \& H.I. Moyano (eds.), Oceanografia en Antártica. Ediciones Documentadas, Santiago: 421-430

Siniff, D.B., R.A. Garrott, J.J. Rotella, W.R. Fraser \& D.G. Ainley 2008. Projecting the effects of environmental change on Antarctic seals. Antarctic Science 20 (5):425-435

Smale, D.A., K.M. Brown, D.K.A. Barnes, K.P.P. Fraser \& A. Clarke 2008. Ice scour disturbance in Antarctic waters. Science 321:371

Smith, V.R., 2002. Climate change in the Subantarctic: an illustration from Marion Island. Climate Change 52:345-357
Smith, W.O. Jr. \& R.F. Anderson 2003. US Southern Ocean JGOFS Program (AESOPS): part III. Deep-Sea Research, Part II 50:529-531

Smith, T.M. \& R.W. Reynolds 2004. Improved extended reconstruction of SST (1854-1997). Journal and Climate, 17:2466-2477.

Smith, R.C., D.G. Ainley, K. Baker, E. Domack, S. Emslie, B. Fraser, J.P. Kennett, A. Leventer, E. Mosley-Thompson, S. Stammerjohn \& M. Vernet 1999. Marine ecosystem sensitivity to climate change. BioScience 49:393-404

Spindler, M. \& G. Dieckmann 1994. Ecological significance of the sea ice biota. In: Hempel, G. (ed.) Antarctic Science- Global Concerns. Springer, Berlin: 60-68

Steig, E.J., D.P. Schneider, S.D. Rutherford, M.E. Mann, J.C. Comiso \& D.T. Shindell 2009. Warming of the Antarctic ice-sheet surface since the 1957 International Geophysical Year. Nature 457:459-462

Strass, V.H. 2002. Mesoscale physics, biogeochemistry and ecology of the Antarctic Polar Front, Atlantic sector. Deep Sea Research. II, 49 (18):3707-3950

Tavares, M. \& G.A.S. Melo 2004. Discovery of the first known benthic invasive species in the Southern Ocean: the North Atlantic spider crab Hyas araneus found in the Antarctic Peninsula. Antarctic Science, 16:129-131

Teixidó, N., J.M. Gili, M.J. Uriz, J. Gutt \& W.E. Arntz 2006. Observations of asexual reproductive strategies in Antarctic hexactinellid sponges from ROV video records. Deep Sea Research II, 53:972-984

Thatje, S. \& A. Brown 2009. The macrobenthic ecology of the Straits of Magellan and the Beagle Channel. Anales Instituto Patagonia (Chile), 37:17-27

Thatje, S., and V. Fuentes 2003. First record of anomuran and brachyuran larvae (Crustacea: Decapoda) from Antarctic waters. Polar Biology, 26:279-282

Thatje, S., K. Anger, J.A. Calcagno, G.A. Lovrich, H.O. Pörtner \& W.E. Arntz 2005. Challenging the cold: crabs re-conquer the Antarctic. Ecology, 86:619-625

Thiel, M. \& L. Gutow 2004. The ecology of rafting in the marine environment. I. The floating 
substrata. Oceanography and Marine Biology Annual Review, 42:181-264

Thomas, D.N. \& G.S. Dieckmann 2003. Sea Ice. An Introduction to its Physics, Chemistry, Biology and Geology. Blackwell, Oxford. 402 pp.

Turner, J., R. Bindschadler, P. Convey, G. di Prisco, E. Fahrbach, J. Gutt, D. Hodgson, P. Mayewski \& C. Summerhayes 2009. Antarctic climate change and the environment. SCAR \& Scott Polar Research, Cambridge: 526 pp.

Vaughan, D.G. \& C.S.M. Doake 1996. Recent atmospheric warming and retreat of ice shelves on the Antarctic Peninsula. Nature, 379:328-330

Vaughan, D.G., G.J. Marshall, W.M. Connolley, C. Parkinson, R. Mulvaney, D.A. Hodgson, J.C. King, C.J. Pudsey \& J. Turner 2003. Recent rapid climate warming on the Antarctic $\mathrm{Pe}$ ninsula. Climate Change, 60:243-274

Warren, C. \& M. Aniya 1999. The calving glaciers of southern South America. Global and Planetary Change, 22:59-77
WBGU (German Advisory Council on Global Change) 2006. The Future Oceans - Warming Up, Rising High, Turning Sour. Berlin: 110 pp. Whitehouse, M.J., M.P. Meredith, P. Rothery, A. Atkinson, P. Ward \& R.E. Korb 2008. Rapid warming of the ocean at South Georgia, Southern Ocean during the 20th century: forcings, characteristics and implications for lower trophic levels. Deep-Sea Research Part I, 55(10):1218-1228

Wiencke, C., G.A. Ferreyra, D. Abele \& S. Marenssi (eds.) 2008. The Antarctic ecosystem of Potter Cove, King George Island (Isla 25 de Mayo). Berichte für Polarforschung und Meeresforschung, 571:406 pp.

Woehler, E. \& J.P. Croxall 1997. The status and trends of Antarctic and sub-Antarctic seabirds. Marine Ornithology, 25:43-66

Zwally, H.J, J.C. Comiso, C.L. Parkinson, D.J. Cavalieri \& P. Gloersen 2002. Variability of Antarctic sea ice 1979-1998. Journal of Geophysical Research, 10:3041, doi:3010.1029/2000JC000733 
W. ARNTZ \& D. GERDES 